\title{
Effect of bioagent application time against bacterial leaf blight of rice caused by Xanthomonas oryzae pv. oryzae (Uyeda and Ishiyama) Dowson
}

\author{
Gokil Prasad Gangwar* and A. P. Sinha \\ Department of Plant Pathology, G. B. Pant University of Agriculture and Technology, Pantnagar, 263 145, INDIA \\ *Corresponding author. E-mail: gokil_prasad@rediffmail.com
}

Received: February 3, 2014; Revised received: March 20, 2014; Accepted: March 31, 2014

\begin{abstract}
Present investigation was carried out to test the effect of time of application on efficacy of Trichoderma harzianum and Pseudomonas fluorescens formulations against bacterial leaf blight of rice, under field condition. Foliar sprays with bioagent(s) in three time sequences i.e. 7 days before, simultaneously and 7 days after inoculation of Xanthomonas oryzae pv. oryzae inoculation significantly reduced disease severity over check during Kharif 2006 and 2007. Maximum reduction in bacterial leaf blight disease was obtained with the application of T. harzianum on 7 days before inoculation of pathogen during Kharif 2006 and 2007 and maximum increase in grain yield was obtained with the application of PBA-2 seven days before inoculation of pathogen. It was revealed that prophylactic spray of bioagents one week prior to pathogen inoculation was significantly $\left(10^{6} \mathrm{cfu} / \mathrm{g}\right)$ effective in reducing disease severity of bacterial leaf blight of rice as compared to chemical treatment.
\end{abstract}

Keywords: Bacterial leaf blight of rice, Pseudomonas fluorescens, Time of application, Trichoderma harzianum, Xanthomonas oryzae pv. oryzae

\section{INTRODUCTION}

Bacterial leaf blight disease of rice caused by Xanthomonas oryzae pv. oryzae (Uyeda and Ishiyama) Dowson is the disease of great economic importance in all rice growing areas of the world and is particularly destructive in South East Asia (Mew et al., 1993 and FAOSTAT, 2002). The disease is known to occur in epidemic proportions in many parts of the world. The disease has been reported from almost all the rice growing states of India where it causes severe yield loss (Singh, 1972). Several bacterial plant pathogens are reported to exhibit antibiotic resistance (McManus et al., 2002). Non-availability of effective chemical control measures and inconsistent performance of resistant rice varieties have forced the plant pathologists to new approaches of disease management. Interest in biological management has increased considerably in the recent past due to their added advantages over the other methods of disease management. Besides disease management, bioagents also stimulate plant growth, even if there is no disease, which results in better yield (Mishra and Sinha, 2000). Antagonistic potential of different bioagents against bacterial leaf blight of rice has been reported by several workers (Vidhyasekaran et al., 2001; Manmeet and Thind, 2002; Babu and Thind, 2005; Palaniyandi et al., 2006; Gangwar and Sinha, 2012a,b,c and Gangwar, 2013a,b). Time of application of bioagents may have effect on efficacy of bioagents as these are living entity and need a period of time for upsurge optimum population and establish on host. The level of management of disease depends on time of application of bioagents. Influence of time of application of bioagents in plant disease management was studied by several workers including Sindhan et al. (1997) and Vidhyasekaran et al. (2001). Present study was carried out to test the effect of time of application on efficacy of $T$. harzianum and $P$. fluorescens formulations against bacterial leaf blight of rice under field conditions.

\section{MATERIALS AND METHODS}

The experiment was conducted at Crop Research Center, G. B. Pant University of Agriculture and Technology, Pantnagar.

Field experiment: Layout of experimental plot was prepared according to randomized block design (RBD). Nursery of susceptible rice cultivar Jaya was raised separately and 21 days old seedling were transplanted in experimental plots. General agronomic practices were followed for cultivation of experimental plots. This experiment was carried out in Kharif sessions, 2006 and 2007.

Mass multiplication of fungal and bacterial bioagents and preparation of formulation: Two commercial formulations of $T$. harzianum (PBA-1) and P. fluorescens (PBA-2) obtained from Bio-control Laboratory, Department of Plant Pathology, G.B. Pant University of Agriculture and Technology, Pantnagar and formulation of $T$. harzianum (rice leaf isolate), were evaluated. Trichoderma spp. was mass ISSN : 0974-9411 (Print), 2231-5209 (Online) All Rights Reserved @ Applied and Natural Science Foundation www.ansfoundation.org 
multiplied on barnyard millet: Echinocloa frumentacae (local name: Jhangora) grains. Jhangora grains colonized by Trichoderma were air dried in open shade and ground with the help of Willy Mill to get fine powder. This powder was passed through 50 and 80 mesh sieves, simultaneously to obtain spore powder. The formulations of fungal bioagent was prepared by diluting spore powder with talcum powder $(\mathrm{mesh}=$ 350 with $95 \%$ whiteness) and $1 \%$ carboxyl methyl cellulose $(\mathrm{CMC})$ to get desired concentration $\left(10^{6} \mathrm{cfu} /\right.$ g) of bioagents in the formulation.

Pathogen inoculation and application of bioagent formulations: Pathogen was inoculated at maximum tillering stage by clipping off the leaf tip @ $10^{6}$ cell $/ \mathrm{ml}$ inoculum (Kauffman et al., 1973). T. harzianum formulation and three commercial formulations viz. PBA-2, PBA-3 and Sudocel were also used in the present study (Table 1). All bioagent formulations and chemical treatment [streptocycline $(0.03 \mathrm{~g} / \mathrm{l}$ water $)+$ copper oxychloride (1 g/l water)] were applied against bacterial leaf blight disease on transplanted rice. Foliar spray of bioagents and chemical treatment were given on three time sequences viz. one week before, simultaneously and one week after pathogen inoculation. Bioagents were applied as foliar spray @ $10 \mathrm{~g} / \mathrm{l}$, while check plots were sprayed with water only. Each treatment was replicated thrice.

Data collection: Data was recorded as percent disease severity on artificially inoculated leaves (average 50 leaves/plot) at 21 and 28 days after treatment application. After harvesting, yield components (number of filled grains per plants, grain yield and 1000 grain weight) were recorded.

Statistical analysis: Statistical analysis of the data obtained from field experiment was done using appropriate programme as per the requirement of the experiment. The critical difference (CD) was calculated at $5 \%$ level of significance for comparison of difference between the means of different treatments.

\section{RESULTS AND DISCUSSION}

Effect of bioagent application time on disease severity: All three time of bioagent application significantly reduced (upto 53.80 and $54.72 \%$ ) mean disease severity over check during Kharif 2006 and 2007,

respectively (Table 2). Application of bioagents, 7 days before pathogen (X. oryzae pv. oryzae) inoculation was as effective as chemical treatment in reducing mean disease severity during Kharif 2006. All bioagent formulations were found to be significantly effective in reducing mean disease severity (53.88 to $44.11 \%)$ over check $(71.33 \%)$. Trichoderma harzianum (44.11\%) and PBA-2 $(45.11 \%)$ were most effective and statistically equal to chemical treatment $(43.00 \%)$ in order to reducing mean disease severity as compared to check. All bioagent formulations were significantly effective in reducing mean disease severity over check at all the three times of bioagent application. All bioagent formulations inoculation (41.66 to $32.33 \%$ ) were statistically as effective as chemical treatment $(42.00 \%)$ when these were applied 7 days before pathogen inoculaion. T. harzianum (43.33\%), PBA-2 (43.33\%) and PBA-3 (48.33\%) were also found to be statistically equal to chemical treatment (41.66) in reducing mean disease severity even when applied simultaneously with pathogen inoculation. $T$. harzianum exhibited maximum percent reduction $(53.80,39.47$, and $21.62 \%)$ in disease severity at all three time of application ( 7 days before, simultaneously and 7 days after pathogen inoculation, respectively).

During Kharif 2007, all three time of bioagent application (61.72 to $44.63 \%$ ) were significantly effective in reducing mean disease severity over check $(73.44 \%)$. Mean disease severities in all treatments (56.50 to $44.11 \%$ ) were significantly lower than check (73.44\%). The effectivity of T. harzianum (44.11\%), PBA-2 (46.11\%) and PBA-3 (48.55) was statistically equal to chemical treatment $(48.05 \%)$. Application of bioagent formulations, 7 days before pathogen inoculation was significantly superior then chemical treatment in order to reducing disease severity. Statistically, T. harzianum $(32.83 \%)$ and PBA-2 $(35.00 \%)$ were found to be better than chemical treatment (43.33). Sudocel (44.33\%) and PBA-3 $(40.33 \%)$ was equally effective to chemical treatment $(43.33 \%)$ in decreasing disease severity when applied 7 days before pathogen inoculation. At simultaneous application of bioagent with pathogen inoculation, $T$. harzianum (42.16\%), PBA-2 (45.83\%) and PBA-3 $(49.16 \%)$ exhibited statistically equal effectivity to chemical treatment $(42.50 \%)$ in reduction of mean disease severity.

When bioagent formulations were applied 7 days after pathogen inoculation, PBA-3 (56.16\%), T. harzianum $(57.33 \%)$ and PBA-2 $(57.50 \%)$ was found equal to chemical treatment $(58.33 \%)$ in the reduction of disease severity but all of these were found significantly effective over check $(75.00 \%)$. Highest percent reduction $(54.39 \%)$ in disease severity was

Table 1. List of bioagent formulations and fungal/bacterial bioagants.

\begin{tabular}{|c|c|}
\hline Bioagent formulations & $\begin{array}{l}\text { Fungal/bacterial } \\
\text { bioagants }\end{array}$ \\
\hline $\begin{array}{l}\text { Trichoderma } \\
\text { harzianum }\end{array}$ & $\begin{array}{l}\text { T. harzianum } \\
\text { (rice leaf isolate) }\end{array}$ \\
\hline PBA-2 & $\begin{array}{l}\text { Pseudomonas fluorescens } \\
\text { PBAP-27 }\end{array}$ \\
\hline PBA-3 & $\begin{array}{l}\text { T. harzianum } \mathrm{PBAT}-43+ \\
P . \text { fluorescens } \mathrm{PBAP}-27\end{array}$ \\
\hline Sudocel* & P. fluorescens \\
\hline
\end{tabular}

* Obtained from market. 
Gokil Prasad Gangwar and A. P. Sinha / J. Appl. \& Nat. Sci. 6 (1): 95-100 (2014)
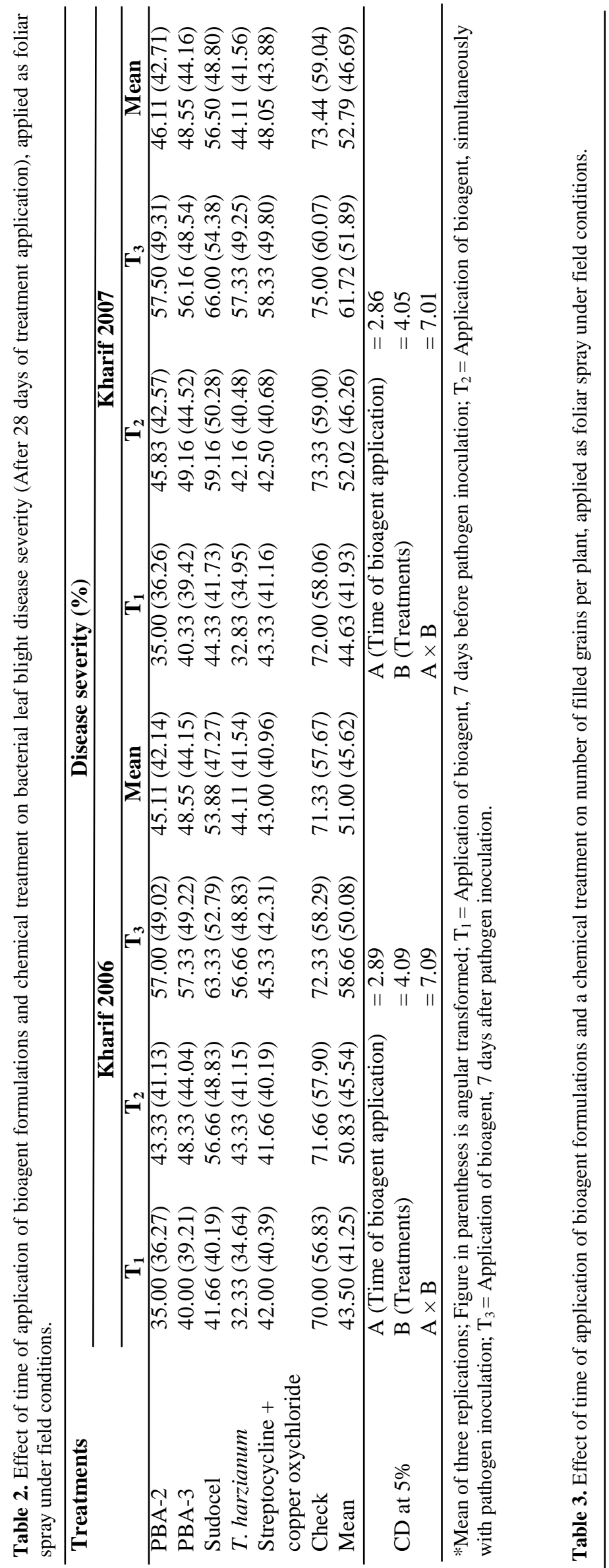

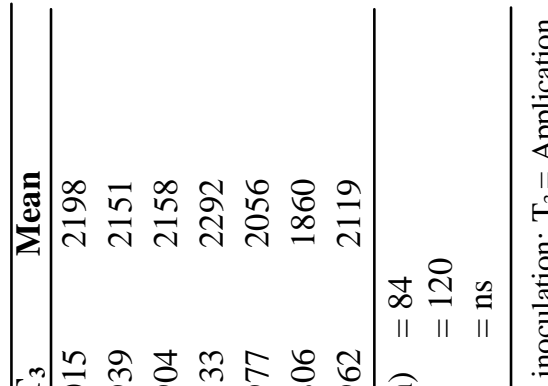

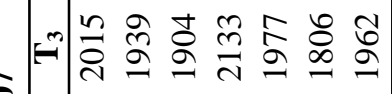

ฮิ

ปั:

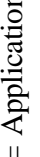

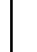

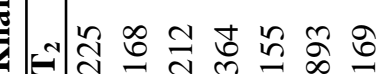

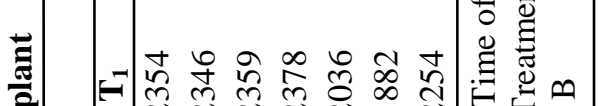

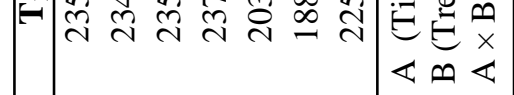

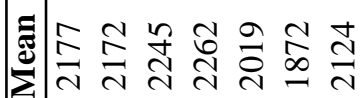

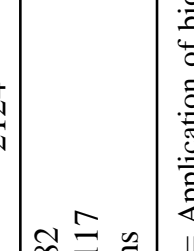

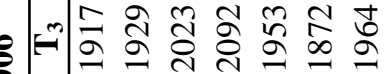
年

药

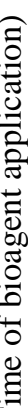

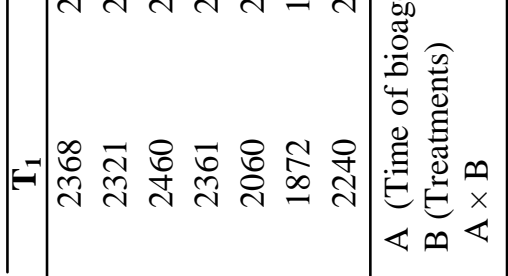

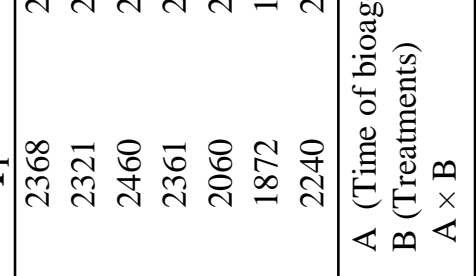

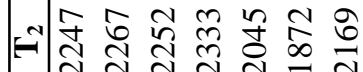

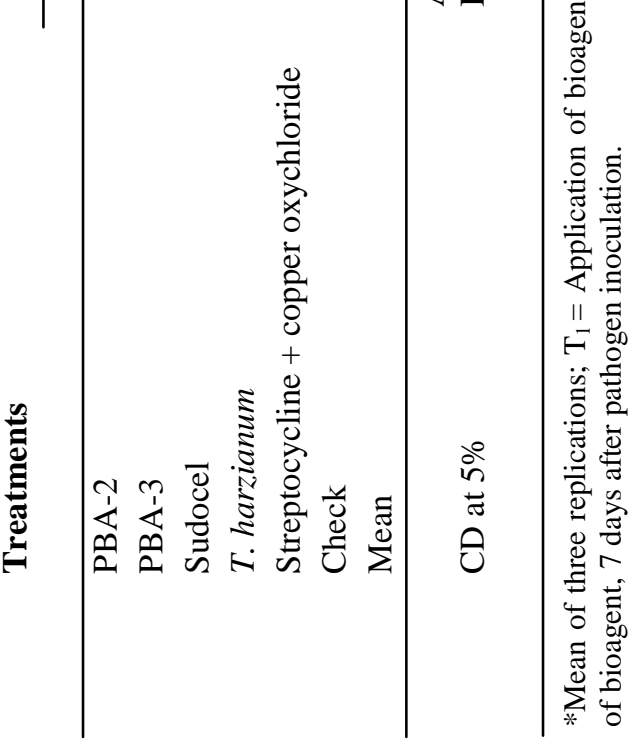




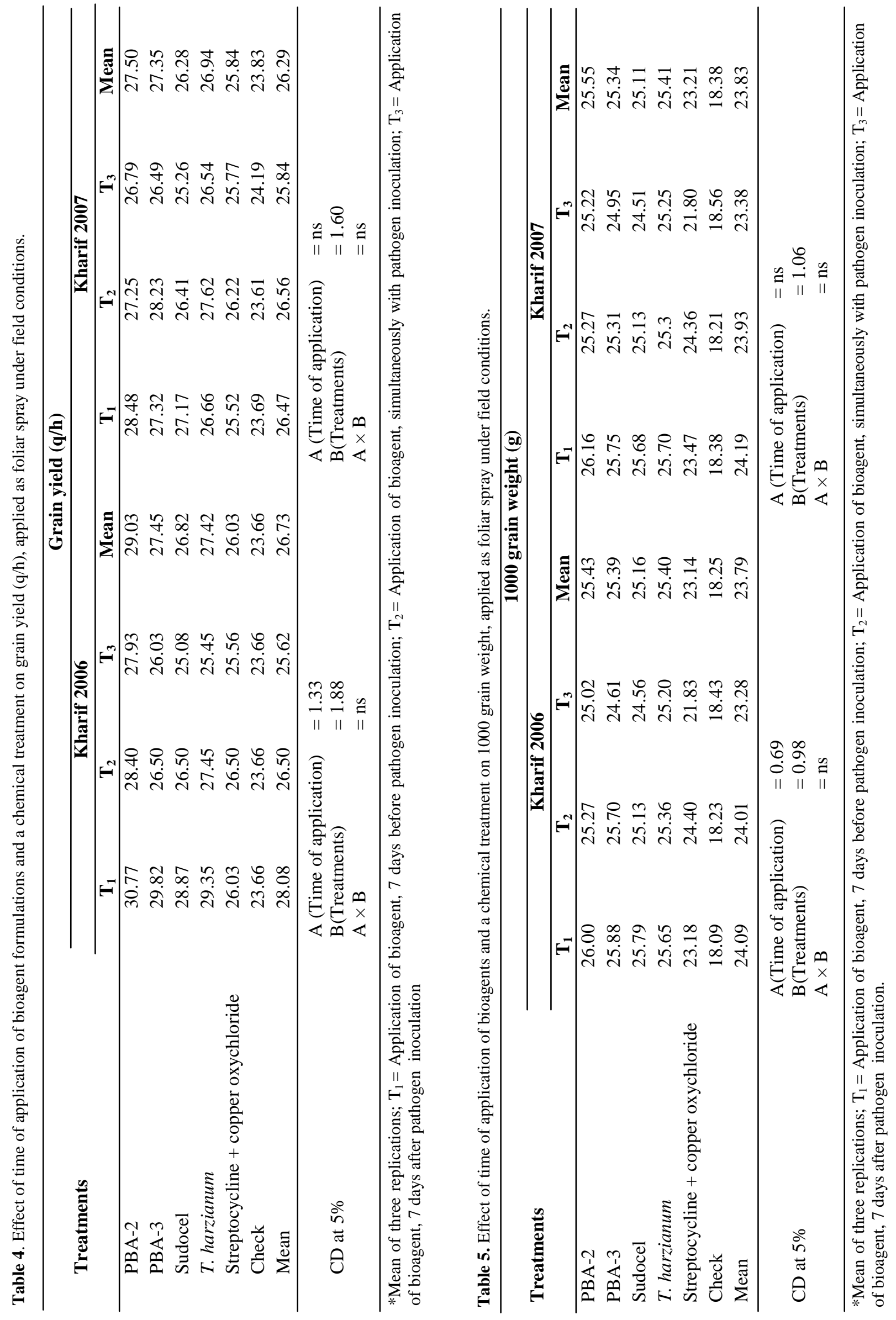


observed with $T$. harzianum when applied 7 days before pathogen inoculation. However, PBA-3 was exhibited highest reduction $(25.11 \%)$ in disease severity when applied 7 days after pathogen inoculation. Higher effectivity of some bioagents over others probably associated with its ability to grow and sporulate and therefore become established in large number on host surface.

Similar results were also observed by Gangwar and Sinha, 2012c under glasshouse conditions. Sindhan et al. (1997) also reported that 7 days pre-inoculation application of antagonists provided significantly greater protection of the bacterial leaf blight disease as compared to post-inoculation. Twenty four hours pre-inoculation application of rice phylloplane microflora was found significantly effective in reducing bacterial leaf blight disease as compared to $0 \mathrm{~h}$ and $24 \mathrm{~h}$ post-inoculation of in the studies of Saikia and Chowdhary (1992). Vidhyasekaran et al. (2001) observed that when the rice leaves were inoculated with $X$. oryzae pv. oryzae 4 days after $P$. fluorescens application, on the flower leaves. The disease intensity was decreased from 6.7 to 1.1 and when rice seeds were treated with the formulation of $P$. fluorescence PF 1 and sown, 30 day old seedling showed resistance to $X$. oryzae pv. oryzae and the disease intensity decreased from 6.8 to 1.2.

Effect of bioagent application time on filled grains per plant: Effect of all the three time of bioagent applications on increasing average number of filled grains per plant was significantly higher (2177 to 2262 and 2151 to 2292) than untreated check (1872 and 1860), during Kharif 2006 and 2007 respectively (Table 3). All bioagents (2177 to 2262) were found to be significantly effective over chemical treatment (2019) and check (1872) in increasing mean number of filled grains per plant, during Kharif 2006. When bioagents were applied 7 days before or simultaneously with pathogen inoculation, they showed significantly higher efficacy (2321 to 2460) as compared to chemical treatment (2060) in increasing mean number of filled grains per plant. When these bioagents were applied 7 days after pathogen inoculation, they (1917 to 2092) were significantly as effective as chemical treatment (1953) in increasing mean number of filled grains per plant. At 7 days before pathogen inoculation, maximum percent increase $(31.38 \%)$ in number of filled grains was obtained with Sudocel. T. harzianum resulted in maximum increase $(11.73 \%)$ in number of filled grains per plant even when applied 7 days after pathogen inoculation.

All bioagents were found to be significantly effective (2151 to 2292) in increasing mean number of filled grains per plant as compared to check (1860), during Kharif 2007. Trichoderma harzianum (2292) and PBA -2 (2198) showed higher effectivity over chemical treatment (2056) in increasing mean number of filled grains per plant. PBA-3 (2151) and Sudocel (2158) were statistically at par with chemical treatment (2056). Application of bioagent formulations 7 days before (2254) and simultaneously with pathogen inoculation (2169) significantly increased mean number of filled grains per plant over chemical treatment (2036 and 2155, respectively). However, application of bioagent formulations 7 days after pathogen inoculation (1904 to 2133) was as effective as chemical treatment (1977). Maximum increase $(26.35,24.84$ and $18.10 \%)$ in mean number of filled grains was recorded with $T$. harzianum at all three time of application ( 7 days before, simultaneously and 7 days after pathogen inoculation, respectively). Similarly, influence of bioagent application on number of filled grains was recorded by Gangwar and Sinha (2012c) under glasshouse conditions.

Effect of bioagent application time on grain yield and 1000 grain weight: All bioagent formulations were significantly effective in increasing mean grain yield ( 26.82 to 29.03 and 26.28 to $27.50 \mathrm{q} / \mathrm{h}$ ) and 1000 grain weight ( 25.16 to 25.43 and 25.11 to $25.55 \mathrm{~g}$ ) as compared to check, during Kharif 2006 and 2007 respectively (Table 4 and 5). Mean grain yield (25.62 to $28.08 \mathrm{q} / \mathrm{h}$ ) and 1000 grain weight (23.28 to $24.19 \mathrm{~g}$ ) at different time of bioagent application were also higher than check, during Kharif 2006 and 2007. Bioagent formulation, PBA-2 exhibits significantly higher mean grain yield $(29.03 \mathrm{q} / \mathrm{h})$ over chemical treatment $(26.03 \mathrm{q} / \mathrm{h})$ whereas, all other bioagent formulations resulted mean grain yield statistically equal to chemical treatment. All bioagent formulations gave significantly increased mean 1000 grain weight (25.16 to $25.43 \mathrm{~g})$ over chemical treatment $(23.14 \mathrm{~g})$. When bioagent formulations were applied 7 days before pathogen inoculation, significantly higher mean grain yield ( 28.87 to $30.77 \mathrm{q} / \mathrm{h}$ ) was recorded as compared to chemical treatment $(26.03 \mathrm{q} / \mathrm{h})$. Application of bioagent formulation simultaneously or 7 days after pathogen inoculation resulted in increasing mean grain yield were found to be statistically equal to chemical treatment. Increase in mean 1000 grain weight was significantly higher than chemical treatment $(23.14 \mathrm{~g})$, when bioagent formulations were applied 7 days before $(24.09 \mathrm{~g})$ and simultaneously with pathogen inoculation $(24.01 \mathrm{~g})$. Increase in mean 1000 grain weight was found statistically equal to chemical treatment when bioagent formulations were applied 7 days after pathogen inoculation. At all three time of application, PBA-2 exhibited maximum percent increase $(30.05,20.03$ and $18.04 \%$, respectively) in grain yield. Maximum percent increase in 1000 grain weight $(43.72 \%)$ was recorded with PBA-2, when applied 7 days before pathogen inoculation. $T$. harzianum exhibited maximum increase $(36.74 \%)$ in 1000 grain weight even when applied 7 days after pathogen inoculation.

All the bioagent formulations were significantly effective in enhancing mean grain yield (26.28 to $27.50 \mathrm{q} / \mathrm{h}$ ) and 1000 grain weight (25.11 to $25.55 \mathrm{~g}$ ), 
during Kharif 2007. PBA-2 (27.50 q/h) showed significantly higher mean grain yield over chemical treatment $(25.84 \mathrm{q} / \mathrm{h})$ while, mean grain yield recorded with all other bioagent formulations (26.28 to 27.35 q/ h) were statistically equal to chemical treatment. All the bioagent formulations were exhibited significantly higher mean 1000 grain weight (25.11 to $25.55 \mathrm{~g}$ ) over chemical treatment $(23.21 \mathrm{~g})$. Maximum increase in grain yield $(20.21 \%)$ and 1000 grain weight $(42.96 \%)$ was observed with PBA-2, when applied 7 days before pathogen inoculation. PBA-2 resulted in maximum increase in grain yield $(10.76 \%)$, while $T$. harzianum resulted in maximum increase in 1000 grain weight (36.48\%) when applied 7 days after pathogen inoculation. Similarly, enhanced grain yield and 1000 grain weight was reported by Gangwar and Sinha (2012c) due to application of bioagent formulation 7 days before inoculation of pathogen under glasshouse conditions. Fungal and bacterial bioagent formulation were found to be effective in increasing grain yield and 1000 grain weight over check and chemical treatment in study carried out in glasshouse by Gangwar and Sinha (2012b).

\section{Conclusion}

On the basis of results of present investigation, it was concluded that different time of application had varied effect on efficacy of bioagent formulations. Prophylactic spray of bioagents one week before pathogen inoculation was significantly effective against bacterial leaf blight of rice as compared to chemical treatment. Application of bioagents one week prior to symptom appearance ( 7 days after pathogen inoculation) was effective against bacterial leaf blight as compared to check. However, the observed results need verification on large scale rice planting.

\section{REFERENCES}

FAOSTAT, (2002). FAO statistic India. File:///A/FAOSTAT Data Base results.com.

Babu, A.G.C. and Thind, B.S. (2005). Potential use of combinations of Pantoea agglomerans, Pseudomonas flourescenc and Bacillus subtilis as biocontrol agents for the control of bacterial blight of rice. Annals of the Sri Lanka, department of agriculture, 7: 23-37.

Gangwar, G.P. (2013a). Efficacy of different isolates of fluorescent pseudomonads against bacterial leaf blight of rice. Afr. J. Agric. Res., 8(37): 4588-4591.

Gangwar, G.P. (2013b). Field efficacy of formulation of fungal bioagents against bacterial leaf blight of rice caused by Xanthomonas oryzae pv. oryzae (Uyeda and Ishiyama) Dowson. J. Appl. \& Nat. Sci., 5(2): 423-426.

Gangwar, G.P. and Sinha, A.P. (2012a). Comparative antagonistic potential of fungal and bacterial bioagents against Xanthomonas oryzae pv. oryzae. Ann. Pl. Protec. Sci., 20(1): 154-159.

Gangwar, G.P. and Sinha, A.P. (2012b). Evaluation of Trichoderma spp. and fluorescent pseudomonads for the management of bacterial leaf blight of rice. Indian Phytopath., 65 (1): 89-91.

Gangwar, G.P. and Sinha, A.P. (2012c). Effect of time of application on fungal and bacterial bioagents against bacterial leaf blight of rice. Agric. Sci. Digest., 32(2): 123-127.

Kauffman, H.E., Reddy, A.P.K., Heisk, S.P.V. and Maraca, S.D., (1973). An improved technique for evaluating resistance of rice varieties to Xanthomonas oryzae. Plant Dis. Rep., 57: 537-541.

Manmeet, M. and Thind, B.S. (2002). Management of bacterial blight of rice with bioagents. Plant Dis. Res., 17(1): 21-28.

McManus, P.S., Stockwell, V.O., Sundin, G.W. and Jones, A.L. (2002). Antibiotic use in plant agriculture. Annu. Rev. Phytopathol., 40: 443-465.

Mew, T.W., Alvarez, A.M., Leach, J.E. and Swings, J. (1993). Focus on bacterial blight of rice. Plant Dis., 77 (1): 5-12.

Mishra, D.S. and Sinha, A.P. (2000). Plant growth promoting activity of some fungal and bacterial agents on rice seed germination and seedling growth. Trop. Agric., 77: 188-191.

Palaniyandi, V., Immanuel, J.E., Gnanamanickam, S.S. and Thomashow. L. (2006). Biological control of rice bacterial blight by plant associated bacteria producing 2,4-diacetylphloroglucinol. Canadian Journal of Microbiology, 52(1): 56-65.

Saikia, P. and Chowdhary, H.D. (1993). Phylloplane microflora for the control of bacterial leaf blight of rice caused by Xanthomonas oryzae pv. oryzae. Indian Phytopath., 46: 218-223.

Sindhan, G.S. Parasher, R.D. and Hooda, I. (1997). Biological control of bacterial leaf blight of rice caused by Xanthomonas oryzae pv. oryzae. Plant Dis. Res., 12 (1): 29-32.

Singh, R.N. (1972). Bacterial blight disease of rice in India. PANS. 18:396-401.

Vidhyasekaran, P., Kamala, N., RamanathanP, A., Rajappan, K., Paranidharan, V. and Velazhahan, R. (2001). Induction of systemic resistance by Pseudomonas fluorescens Pf1 against Xanthomonas oryzae pv. oryzae in rice leaves. Phytoparasitica. 29(2): 155-166. 